\title{
Heat-stable ureases from two filamentous cyanobacteria
}

\author{
Thomas Jahns, Udo Schäfer and Heinrich Kaltwasser
}

Author for correspondence: Thomas Jahns. Tel: +49681 3022745. Fax: +496813023986.

e-mail: toja@,rz.uni-sb.de

Institut für Mikrobiologie, Fachrichtung 13.3,

Universităt des Saarlandes, D-66041 Saarbrücken, Germany

\begin{abstract}
Ureases of the cyanobacteria Leptolyngbya boryana (Plectonema boryanum) PCC 73110 and AnabaenalNostoc PCC 7120 were purified more than 1500-fold to homogeneity by heat treatment and liquid chromatography, reaching specific activities of up to $350 \mathrm{U}$ (mg protein) ${ }^{-1}$. Both enzymes had a molecular mass of $220 \mathrm{kDa}$, as shown by native PAGE, and consisted of three subunits $(\alpha$, $\beta_{r} \gamma$ ) with molecular masses of $66 \mathrm{kDa}(\alpha), 18 \mathrm{kDa}$ (Leptolyngbya; $\beta$ ) or $14 \mathrm{kDa}$ (AnabaenalNostoc; $\beta$ ) and $11 \mathrm{kDa}(\gamma)$. The enzyme of Leptolyngbya exhibited maximum activity at pH 8.2 and $60^{\circ} \mathrm{C}$, and that of AnabaenalNostoc at pH 8.5 and $65^{\circ} \mathrm{C}$; the $K_{\mathrm{m}}$ was $0.25 \mathrm{mM}$ urea for both organisms. Almost identical specific activities were observed in cells grown with urea, ammonia, nitrate or dinitrogen as the source of nitrogen. The ureases from both organisms were heat-stable; no loss of activity was observed during incubation at $70^{\circ} \mathrm{C}$ for $15 \mathrm{~min}$.
\end{abstract}

Keywords: urease, purification, cyanobacteria, Leptolyngbya, Anabaena/Nostoc

\section{INTRODUCTION}

The ability to metabolize urea is widespread among micro-organisms (Barth \& Michel, 1971); in some fungi and green algae, urea is first carboxylated to yield allophanate, which is then hydrolysed to two molecules of ammonia and carbon dioxide (Leftley \& Syrett, 1973; Roon \& Levenberg, 1972). Cyanobacteria are well known to utilize urea as a source of nitrogen for growth (McLachlan \& Gorham, 1962; Berns et al., 1966). In cyanobacteria, as in all other urea-utilizing bacteria studied so far (for a review, see Mobley \& Hausinger, 1989, and references therein), the enzyme urease (urea amidohydrolase; EC 3.5.1.5) catalyses the hydrolysis of urea to ammonia and carbamate; carbamate decomposes spontaneously to carbon dioxide and a second molecule of ammonia.

Earlier studies concerning the structural properties of bacterial ureases led to conflicting results. Most ureases, e.g. those from Klebsiella aerogenes ( $K$. pneumoniae) (Mulrooney \& Hausinger, 1990), Proteus mirabilis (Breitenbach \& Hausinger, 1988), Proteus vulgaris (Mörsdorf \& Kaltwasser, 1990) or Providencia stuartii (Mulrooney et al., 1988), were shown to be composed of three different types of subunit, designated $\alpha, \beta$ and $\gamma$. In contrast, the ureases of Bacillus pasteurii and Selenomonas ruminantium were first described as being homopolymeric, consisting only of the large subunits (Christians \& Kaltwasser, 1986; Hausinger, 1986). Subsequent studies on the enzyme of $S$. ruminantium (Todd \& Hausinger, 1987) and B. pasteurii (T. Jahns, unpublished), however, revealed that ureases from these Gram-positive organisms are similar with regard to their subunit composition $(\alpha, \beta$, $\gamma)$ to those of the Gram-negative bacteria studied. It appears that the small subunits may have been overlooked in SDS-PAGE gels which were too low in acrylamide concentration.

The ureases of the cyanobacteria Spirulina maxima (Carvajal et al., 1982), Anabaena doliolum (Rai, 1989) and Anabaena cylindrica (Argall et al., 1992) appear to differ from those of other bacteria, being homopolymeric enzymes, composed of six subunits of molecular mass between 32 and $38 \mathrm{kDa}$. Apparently, however, none of these cyanobacterial enzymes were purified to homogeneity. We therefore started a more detailed study of the ureases of the two filamentous cyanobacteria, Leptolyngbya boryana (Plectonema boryanum) PCC 73110 and Anabaena/Nostoc PCC 7120. The ureases from these organisms turned out to be thermostable enzymes similar to other ureases of prokaryotic origin with regard to their subunit composition, but different from the cyanobacterial ureases described so far.

\section{METHODS}

Materials. All chemicals and reagents were of at least analytical grade. Molecular mass standard proteins were from Boehringer or Sigma. Q-Sepharose FF, Phenyl-Sepharose HL, Sephacryl 
S300HR and Mono-Q were purchased from Pharmacia. The media and the buffers used for enzyme purification were prepared with Milli-Q-purified water (Millipore).

Organisms, growth conditions and preparation of extracts. Leptolyngbya boryana (Plectonema boryanum) PCC 73110 and Anabaena/Nostoc PCC 7120 were obtained from the Pasteur Culture Collection, Paris, France. The cells were grown to late exponential phase with slow shaking or stirring at $28^{\circ} \mathrm{C}$ and $3000 \mathrm{~lx}$ (Osram 36W/21, Lumilux cool white) in medium BG11 (Rippka et al., 1979), to which $10 \mathrm{mM}$ filter-sterilized $\mathrm{NaHCO}_{3}$ was added. In one set of experiments, sodium nitrate was replaced by other nitrogenous compounds; $15 \mathrm{mM}$ sodium chloride was added to these media. Purity was assessed by microscopic examination and by regular streaking of the strains on solidified BG11, supplemented with $0.2 \%(\mathrm{w} / \mathrm{v})$ glucose and $0.02 \%(\mathrm{w} / \mathrm{v}$ ) Casamino acids (Rippka et al., 1979). Cells were harvested by centrifugation $\left(20000 \mathrm{~g}\right.$ for $30 \mathrm{~min}$ at $4^{\circ} \mathrm{C}$ ) and washed twice in $50 \mathrm{mM}$ sodium phosphate, $1 \mathrm{mM} \mathrm{Na}{ }_{2}$ EDTA, $\mathrm{pH} 7 \cdot 0$ (buffer $\mathrm{A}$ ). Cells were disintegrated by ultrasonification of cell suspensions containing approximately $0.3 \mathrm{~g}$ wet weight per $\mathrm{ml}$ buffer A. Ultrasonic treatment lasted a total of $30 \mathrm{~s} \mathrm{ml}^{-1}$, applied in periods of $15 \mathrm{~s}$ with intermittent cooling in an ice bath, using a Branson sonifier B12 at no more than $60 \mathrm{~W}$, and was followed by centrifugation for $30 \mathrm{~min}$ at $45000 \mathrm{~g}$ in order to obtain cell-free extracts.

Measurement of enzyme activity and protein. Urease activity was determined by measuring the amount of ammonia liberated from urea by the indophenol method (Chaney \& Marbach, 1962 ) or in an NADH-dependent coupled enzyme assay according to the method of Kaltwasser \& Schlegel (1966). Fractions eluting from the Phenyl-Sepharose column and containing high amounts of ammonium were only qualitatively assayed for urease activity by a $\mathrm{pH}$ indicator assay using phenol red (Hamilton-Miller \& Gargan, 1979). One unit of enzyme activity $(\mathrm{U})$ is defined as the decomposition of $1 \mu \mathrm{mol}$ urea $\mathrm{min}^{-1}$ at $30^{\circ} \mathrm{C}$ and $\mathrm{pH} 8.0$; specific activities are expressed as $\mathrm{U}(\mathrm{mg}$ protein $)^{-1}$. Protein was determined according to the Lowry method using bovine serum albumin as a standard.

Electrophoresis. For the determination of the molecular mass of the subunits, samples from different stages of purification were analysed by SDS-PAGE in a Biometra Minigel system according to Laemmli (1970). Native gel electrophoresis was carried out at $4{ }^{\circ} \mathrm{C}$ in horizontal ultrathin gels $(240 \times 125 \times 0.5 \mathrm{~mm})$ at a gradient of 4 to $32 \%$ polyacrylamide $(\mathrm{C}=3 \%)$. The gels were separated at $8000 \mathrm{Vh}$ and subsequently silver-stained for protein visualization according to Merril et al. (1981) or for activity as described by Fishbein (1969).

Purification of urease. All the steps in the purification of the enzyme from both cyanobacteria were carried out at between 22 and $28^{\circ} \mathrm{C}$, except size-exclusion chromatography, which was performed at $4{ }^{\circ} \mathrm{C}$, and heat treatment, performed at $70^{\circ} \mathrm{C}$.

(i) Heat treatment. Extracts of cells grown in medium BG11 were heated with continuous stirring at $70^{\circ} \mathrm{C}$ for $15 \mathrm{~min}$; they were centrifuged for $30 \mathrm{~min}$ at $45000 \mathrm{~g}$ and $4{ }^{\circ} \mathrm{C}$ and the pellets were discarded.

(ii) Binding to Q-Sepharose. The supernatant was loaded onto a Q-Sepharose FF column $\left(2 \mathrm{~cm}^{2} \times 10 \mathrm{~cm}\right)$ connected to an HPLC system (LKB, Bromma; pump 2150, detector 2158 uvicord SD, fraction collector 2211 superrac, controller 2152 LC) and equilibrated with buffer $\mathrm{A}$. Proteins were eluted using a linear gradient from 0.1 to $1.0 \mathrm{M} \mathrm{NaCl}$ in buffer $\mathrm{A}$ with a flow rate of $2.0 \mathrm{ml} \mathrm{min}{ }^{-1}$. Elution of protein was followed at $280 \mathrm{~nm}$, and five $4.0 \mathrm{ml}$ fractions with the highest urease activity, eluting at a concentration of about $0.43 \mathrm{M} \mathrm{NaCl}$ (Leptolyngbya) or $0.40 \mathrm{M}$ $\mathrm{NaCl}$ (Anabaena/Nostoc), were pooled. (iii) Hydrophobic interaction chromatography. The fractions containing urease activity (total volume $20 \mathrm{ml}$ ) were adjusted to $1.0 \mathrm{M}\left(\mathrm{NH}_{4}\right)_{2} \mathrm{SO}_{4}$ by adding $10 \mathrm{ml} 3.0 \mathrm{M}\left(\mathrm{NH}_{4}\right)_{2} \mathrm{SO}_{4}$ and loaded onto a Phenyl-Sepharose HL column $\left(2 \mathrm{~cm}^{2} \times 12 \mathrm{~cm}\right)$ connected to the LKB HPLC system, previously equilibrated with buffer A, containing $1 \mathrm{M}\left(\mathrm{NH}_{4}\right)_{2} \mathrm{SO}_{4}$. In a linear gradient from 1.0 to $0 \mathrm{M}\left(\mathrm{NH}_{4}\right)_{2} \mathrm{SO}_{4}$, the enzyme of both strains was eluted with a flow rate of $2.0 \mathrm{ml} \mathrm{min}^{-1}$ at $0.40 \mathrm{M}\left(\mathrm{NH}_{4}\right)_{2} \mathrm{SO}_{4}$.

(iv) Size-exclusion chromatography. The two most active $4 \mathrm{ml}$ fractions from the Phenyl-Sepharose column were pooled and applied to a Sephacryl S300HR column $\left(4.9 \mathrm{~cm}^{2} \times 99 \mathrm{~cm}\right)$ connected to the LKB HPLC system. The elution buffer used was buffer $A$ containing $0.1 \mathrm{M} \mathrm{NaCl}$, with a flow of $0.45 \mathrm{ml}$ $\min ^{-1}$. Fractions of $4.5 \mathrm{ml}$ were collected and assayed for urease activity.

(v) Anion-exchange chromatography. The three most active fractions from size-exclusion chromatography were pooled, loaded onto a Mono-Q HR5/5 column connected to the LKB HPLC system and eluted using a linear gradient from $0 \cdot 1$ to $1.0 \mathrm{M} \mathrm{NaCl}$ in buffer $A$ with a flow rate of $1 \mathrm{ml} \mathrm{min}^{-1}$; urease was eluted at approximately $0.42 \mathrm{M} \mathrm{NaCl}$ (Leptolyngbya) or $0.40 \mathrm{M} \mathrm{NaCl}$ (Anabaena/Nostoc).

Reproducibility of results. The table and the figure show representative results from single experiments, which were repeated at least twice. Determination of the $K_{m}$ values was repeated four times and $K_{\mathrm{m}}$ was calculated from LineweaverBurk plots. Linear correlations were fitted by regression analysis, yielding values for $r$ of between 0.988 and 0.996 . Other results are mean values from at least two independent experiments. SD values did not exceed $\pm 20 \%$ of the mean value and are not indicated.

\section{RESULTS AND DISCUSSION}

\section{Purification of cyanobacterial urease}

Leptolyngbya boryana PCC 73110 and Anabaena/Nostoc PCC 7120 showed consistently low levels of urease of about $0.12 \mathrm{U}$ (mg protein) ${ }^{-1}$ and $0.08 \mathrm{U}$ (mg protein) ${ }^{-1}$, respectively. Almost identical specific activities were observed after the growth of both strains in media containing nitrate $(5 \mathrm{mM})$, ammonium $(5 \mathrm{mM})$ or urea $(2.5 \mathrm{mM})$. These findings are similar to observations with Anabaena cylindrica (Mackerras \& Smith, 1986) and Anabaena variabilis (Ge et al., 1990), where urease synthesis was shown to occur regardless of the nitrogen source used for growth; in Anabaena doliolum and Anacystis nidulans, however, urease synthesis was repressed by ammonium (Singh, 1990, 1991).

After purification of urease from nitrate-grown cells of $L$. boryana PCC 73110 by heat treatment and ion-exchange chromatography on Q-Sepharose and Mono-Q, hydrophobic interaction chromatography on Phenyl-Sepharose, and size-exclusion chromatography on Sephacryl S300HR, an enrichment of more than 1500-fold was obtained (Table 1); similar results were obtained for the enzyme of Anabaena/ Nostoc PCC 7120 (data not shown). In order to obtain a homogeneous enzyme preparation, only fractions exhibiting the highest urease activities were used for the subsequent enrichment by column chromatography; this procedure led to the comparatively low recovery of $8 \%$. The highest specific activities obtained 
Table 1. Purification of urease from Leptolyngbya boryana PCC 73110

\begin{tabular}{|lccccc|}
\hline $\begin{array}{l}\text { Purification } \\
\text { step }\end{array}$ & $\begin{array}{c}\text { Total protein } \\
\text { (mg) }\end{array}$ & $\begin{array}{c}\text { Total } \\
\text { activity (U) }\end{array}$ & $\begin{array}{c}\text { Specific activity } \\
\text { [U (mg protein) } \mathbf{~}^{-1} \mathbf{~}^{*}\end{array}$ & $\begin{array}{c}\text { Recovery } \\
\text { (\%) }\end{array}$ & $\begin{array}{c}\text { Purification } \\
\text { factor }\end{array}$ \\
\hline Crude extract & 3574 & 460 & $0 \cdot 129$ & 100 & 1 \\
Heat treatment & 294 & 384 & $1 \cdot 306$ & 84 & 10 \\
Q-Sepharose & 7 & 286 & $40 \cdot 86$ & 62 & 315 \\
Phenyl-Sepharose & ND & ND & ND & ND & ND \\
Sephacryl S300HR & ND & 72 & ND & 16 & ND \\
Mono-Q HR5/5 & $0 \cdot 184$ & $36 \cdot 8$ & $202 \cdot 3$ & 8 & 1568 \\
\hline
\end{tabular}

ND, Not determined.

* Specific activities were determined by measuring the amount of ammonia liberated from urea, except in the fractions eluted from Phenyl-Sepharose, where urease was determined qualitatively by a $\mathrm{pH}$ indicator assay using phenol red, as described in Methods.

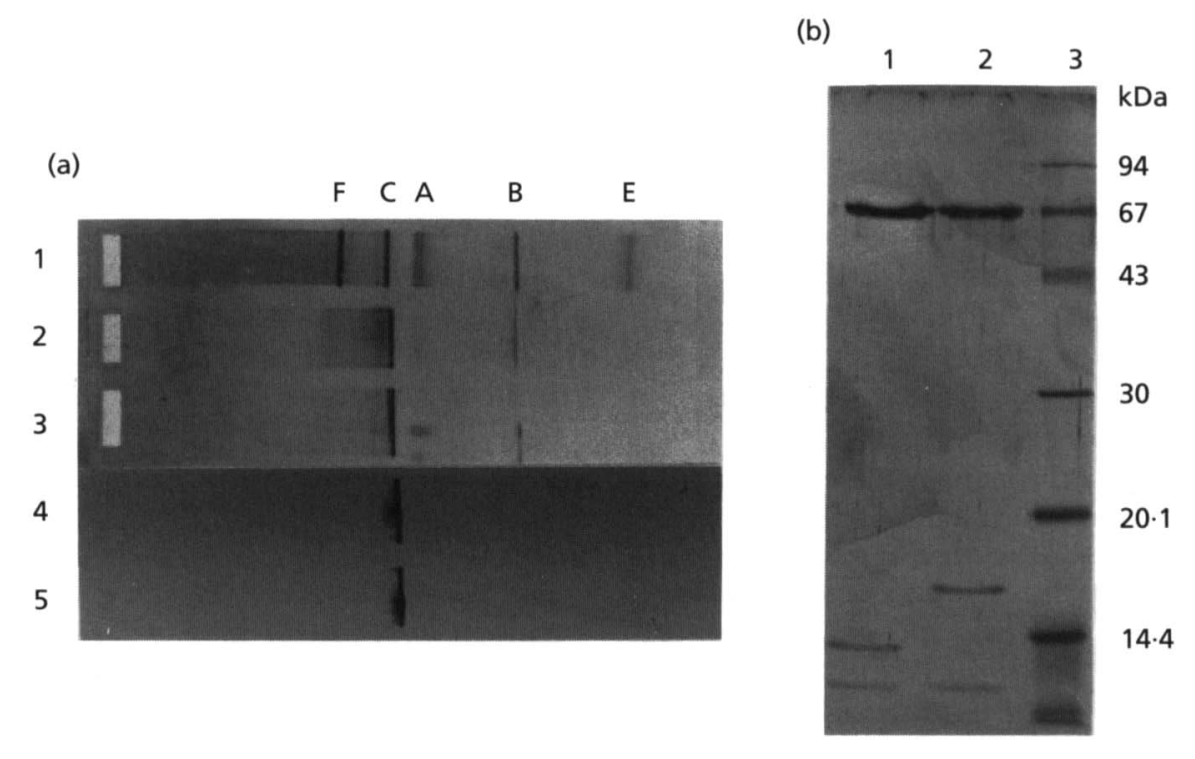

Fig. 1. Native pore gradient electrophoresis (a) or SDS-PAGE (b) of urease from Leptolyngbya boryana PCC 73110 and Anabaena/Nostoc PCC 7120. (a) A homogeneous urease sample with a specific activity of approximately $200 \mathrm{U}$ (mg protein $)^{-1}$ was separated by non-denaturing electrophoresis in $4-32 \%$ polyacrylamide gradient gels. Lanes $1-3$, silver stain: lane 1, molecular mass standards [ferritin ( $450 \mathrm{kDa}$; F), catalase (240 kDa; C), aldolase (158 kDa; A), bovine serum albumin (67 kDa; B) and egg albumin ( $43 \mathrm{kDa}$; E)]; lane 2, urease from Anabaena/Nostoc; lane 3 , urease from $L$. boryana). Lanes 4 and 5, activity stain: lane 4, urease from Anabaena/Nostoc; lane 5, urease from L. boryana. (b) Urease $(0.6 \mu \mathrm{g}$ per lane: lane 1, L. boryana; lane 2, Anabaena/Nostoc) was subjected to SDS-PAGE in a $15 \%$ gel. Proteins were visualized by silver staining. Lane 3, protein standards.

were between 200 and $350 \mathrm{U}$ (mg protein $)^{-1}$ for the urease of both strains, measured at $30^{\circ} \mathrm{C}$. This activity is more than 20 times higher than that observed in purified preparations of other cyanobacterial ureases (Carvajal et al., 1982; Rai, 1989; Argall et al., 1992); in other bacteria, however, much higher specific activities of up to $180000 \mathrm{U}$ (mg protein) ${ }^{-1}$ have been observed (Mobley \& Hausinger, 1989).

\section{Kinetic properties and heat stability}

Using the purified enzyme for all subsequent studies, a $\mathrm{pH}$ optimum of 8.2 (L. boryana) or 8.5 (Anabaena/Nostoc) in both buffer $A$ and $50 \mathrm{mM}$ disodium diethylbarbiturate was determined. The urease of both cyanobacteria exhibited Michaelis-Menten kinetics with a $K_{\mathrm{m}}$ value of $0.25 \mathrm{mM}$ urea, measured at optimal $\mathrm{pH}$ and $30^{\circ} \mathrm{C}$. Maximum activity was obtained at $60^{\circ} \mathrm{C}$ (L. boryana) or $65^{\circ} \mathrm{C}$ (Anabaena/Nostoc).

The enzyme of both strains was remarkably heat-stable; no loss of activity was observed upon incubation for 15 min at temperatures between 30 and $70^{\circ} \mathrm{C}$. At temperatures above $72{ }^{\circ} \mathrm{C}$, a rapid irreversible inactivation occurred. Similar heat-stability was described for the urease of Anabaena variabilis (Ge et al., 1990), and the urease of Providencia rettgeri was stable even at temperatures of up to $80^{\circ} \mathrm{C}$, but only in the presence of its substrate; the activity 
was rapidly lost in its absence (Magana-Plaza et al., 1971). No such protective effect of urea was detected with the urease from L. boryana or Nostoc/Anabaena (results not shown). Both purified enzymes lost approximately $40 \%$ of activity within $5 \mathrm{~d}$ upon storage at $4{ }^{\circ} \mathrm{C}$; immediate and complete loss of activity was observed upon incubation at $-20^{\circ} \mathrm{C}$ in buffer A containing $0.4 \mathrm{M} \mathrm{NaCl}$, whereas no loss of activity was observed under these conditions when $20 \%(\mathrm{v} / \mathrm{v})$ glycerol was added to the enzyme preparation (results not shown).

\section{Molecular mass and subunit composition}

Silver-stained SDS-PAGE gels of purified urease revealed three bands, corresponding to three subunits of $66 \mathrm{kDa}$ $(\alpha), 18 \mathrm{kDa}($ L. boryana; $\beta$ ) or $14 \mathrm{kDa}$ (Anabaena/Nostoc; $\beta)$ and $11 \mathrm{kDa}(\gamma ;$ Fig. 1). This heteromeric subunit composition was observed in every purification, even when purified enzyme was subjected to a second sizeexclusion and ion-exchange chromatography on Mono- $Q$ (results not shown). This suggested that the small subunits were not impurities of the purified enzyme; however, this possibility can not be ruled out with certainty. A composition consisting of $\alpha, \beta$ and $\gamma$ subunits is typical for most bacterial ureases studied so far, of both Grampositive and Gram-negative organisms (for a recent review, see Collins \& D'Orazio, 1993). Subunit molecular masses of between 63 and $73 \mathrm{kDa}(\alpha), 8$ and $17.8 \mathrm{kDa}(\beta)$ and 8 and $16.3 \mathrm{kDa}(\gamma)$ have been observed in other ureases (Mobley \& Hausinger, 1989; Hu et al., 1990; Christians et al., 1991), and the subunit molecular masses of the cyanobacterial ureases studied here are in accordance with these values. However, these two ureases differ in subunit structure from cyanobacterial ureases previously described. Although the molecular masses of the holoenzymes from Spirulina maxima $(232 \mathrm{kDa}$; Carvajal et al., 1982), Anabaena doliolum (228 kDa; Rai, $1989)$ and $A$. cylindrica PCC $7122(197 \mathrm{kDa}$; Argall et al., 1992) are similar to the cyanobacterial ureases studied here, the enzymes of the three former species were described as being hexameric, composed of identical subunits with a molecular mass of between 32 and $38 \mathrm{kDa}$. In these earlier studies, however, urease was only enriched to specific activities of between 1.7 and $10 \mathrm{U}$ (mg protein $)^{-1}$, which might suggest that these enzymes were not purified to homogeneity.

The molecular mass of the native ureases from $L$. boryana and Anabaena/Nostoc was determined by size-exclusion chromatography to be $230 \mathrm{kDa}$ and $240 \mathrm{kDa}$ respectively. In silver-stained native gradient PAGE, major protein bands corresponding to $220 \mathrm{kDa}$ were observed (Fig. 1). A faint band corresponding to a molecular mass of $66 \mathrm{kDa}$ was always observed (Fig. 1), which may be the $\alpha$ subunit, a product of a disintegration of urease into its subunits. Due to their low molecular mass, the smaller subunits $(\beta, \gamma)$ would have passed through the separation gel. When the same gel was stained for urease activity, only one band was observed, corresponding to a molecular mass of $220 \mathrm{kDa}$ (Fig. 1). This result differs from those obtained with a number of non-cyanobacterial ureases, where multiple bands of urease activity were observed in native PAGE (Mobley \& Hausinger, 1989; Schäfer \& Kaltwasser, 1994). This observation was assumed to be due to disintegration of the holoenzyme into catalytically active substructures with different subunit stoichiometry.

In conclusion, we have demonstrated that the ureases from L. boryana PCC 73110 and Anabaena/Nostoc PCC 7120 are heat-stable enzymes, composed of $\alpha, \beta$ and $\gamma$ subunits similar to other bacterial ureases. Our results differ from those reported for other cyanobacteria (Carvajal et al., 1982; Rai, 1989; Argall et al., 1992), and studies with strains belonging to various other genera of cyanobacteria are being carried out in our laboratory to clarify this aspect.

\section{ACKNOWLEDGEMENTS}

The authors would like to thank Rosmarie Rippka for providing the strains used in this study, Ingeborg Thömmes for valuable technical assistance, and Gareth Bartley for proof-reading the manuscript.

\section{REFERENCES}

Argall, M. E., Smith, G. D., Stamford, N. P. J. \& Youens, B. N. (1992). Purification and properties of urease from the cyanobacterium Anabaena cylindrica. Biochem Int 27, 1027-1036.

Barth, A. \& Michel, H. J. (1971). Urease. Pharmazie 26, 321-328.

Berns, D. S., Holohan, P. \& Scott, E. (1966). Urease activity in blue green algae. Science 152, 1077-1078.

Breitenbach, J. M. \& Hausinger, R. P. (1988). Proteus mirabilis urease. Partial purification and inhibition by boric acid and boronic acid. Biochem J 250, 917-920.

Carvajal, N., Fernandez, M., Rodriguez, J. P. \& Donoso, M. (1982). Urease of Spirulina maxima. Phytochemistry 21, 2821-2823.

Chaney, A. L. \& Marbach, E. P. (1962). Modified reagents for the determination of urea and ammonia. Clin Chem 8, 130-132.

Christians, S. \& Kaltwasser, H. (1986). Nickel-content of urease from Bacillus pasteurii. Arch Microbiol 145, 51-55.

Christians, S., Jose, J., Schäfer, U. \& Kaltwasser, H. (1991). Purification and subunit determination of the nickel-dependent Staphylococcus xylosus urease. FEMS Microbiol Lett 80, 271-276.

Collins, C. M. \& D'Orazio, S. E. F. (1993). Bacterial ureases: structure, regulation of expression and role in pathogenesis. Mol Microbiol 9, 907-913.

Fishbein, W. N. (1969). A sensitive and non-inhibitory catalytic gel stain for urease. In Fifth International Symposium on Chromatograpby and Electrophoresis, pp. 238-242. Edited by the Belgian Pharmaceutical Science Society, Brussels. London: Ann HarborHumphrey Science Publishers.

Ge, Xin, Cain, K. \& Hirschberg, R. (1990). Urea metabolism and urease regulation in the cyanobacterium Anabaena variabilis. Can $J$ Microbiol 36, 218-222.

Hamilton-Miller, J. M. T. \& Gargan, R. A. (1979). Rapid screening for urease inhibitors. Invest Urol 16, 327-328.

Hausinger, R. P. (1986). Purification of a nickel-containing urease from the rumen anaerobe Selenomonas ruminantium. J Biol Chem 261, 7866-7870.

Hu, L. T., Nicholson, E. B., Jones, B. D., Lynch, M. J. and Mobley, H. L. T. (1990). Morganella morganii urease: purification, charac- 
terization, and isolation of gene sequences. $J$ Bacteriol 172, 3073-3080.

Kaltwasser, H. \& Schlegel, H. G. (1966). NADH-dependent coupled enzyme assay for urease and other ammonia-producing systems. Anal Biochem 16, 132-138.

Laemmli, U. K. (1970). Cleavage of structural proteins during assembly of the head of bacteriophage T4. Nature 227, 680-685.

Leftley, J.W. \& Syrett, P. J. (1973). Urease and ATP: urea amidolyase activity in unicellular algae. J Gen Microbiol 77, 109-115.

Mackerras, A. H. \& Smith, G. D. (1986). Urease activity of the cyanobacterium Anabaena cylindrica. J Gen Microbiol 132, 2749-2752.

McLachlan, J. \& Gorham, P. R. (1962). Effects of $\mathrm{pH}$ and nitrogen sources on growth of Microcystis aeruginosa Kütz. Can J Microbiol 8, $1-11$.

Magana-Plaza, I., Montes, C. \& Ruiz-Herrera, J. (1971). Purification and biochemical characteristics of urease from Proteus rettgeri. Biochim Biophys Acta 242, 230-237.

Merril, C. R., Goldman, D., Sedman, S. A. \& Ebert, M. H. (1981). Ultrasensitive stain for proteins in polyacrylamide shows regional variation in cerebrospinal fluid proteins. Science 211, 1437-1438.

Mobley, H. L. T. \& Hausinger, R. P. (1989). Microbial ureases: significance, regulation, and molecular characterization. Microbiol Rev 53, 85-108.

Mörsdorf, G. \& Kaltwasser, H. (1990). Cloning of the genes encoding urease from Proteus vulgaris and sequencing of the structural genes. FEMS Microbiol Lett 66, 67-74.

Mulrooney, S. B. \& Hausinger, R. P. (1990). Sequence of the Klebsiella aerogenes urease genes and evidence for accessory proteins facilitating nickel incorporation. J Bacteriol 172, 5837-5843.
Mulrooney, S. B., Lynch, M. J., Mobley, H. L. T. \& Hausinger, R. P. (1988). Purification, characterization and genetic organization of recombinant Providencia stuartii urease expressed in Escherichia coli. $J$ Bacteriol 170, 2202-2207.

Rai, A. K. (1989). Purification and properties of urease from a cyanobacterium Anabaena doliolum. FEMS Microbiol Lett 61, 319-322.

Rippka, R., Deruelles, J., Waterbury, J. B., Herdman, M. \& Stanier, R. Y. (1979). Generic assignments, strain histories and properties of pure cultures of cyanobacteria. J Gen Microbiol 111, 1-61.

Roon, R. J. \& Levenberg, B. (1972). Urea amidohydrolase. I. Properties of the enzyme from Candida utilis. J Biol Chem 247, 4107-4113.

Schafer, U. K. \& Kaltwasser, H. (1994). Urease from Stapbylococcus saprophyticus: purification, characterization and comparison to Staphylococcus xylosus urease. Arch Microbiol 161, 393-399.

Singh, 5. (1990). Regulation of urease activity in the cyanobacterium Anabaena doliolum. FEMS Microbiol Lett 67, 79-84.

Singh, S. (1991). Role of nickel and N-starvation in the regulation of urea metabolism in the cyanobacterium Anacystis nidulans. $J$ Gen Appl Microbiol 37, 325-330.

Todd, M. J. \& Hausinger, R. P. (1987). Purification and characterization of the nickel-containing multicomponent urease from Klebsiella aerogenes. J Biol Chem 262, 5963-5967.

Received 14 September 1994; revised 4 November 1994; accepted 22 November 1994. 